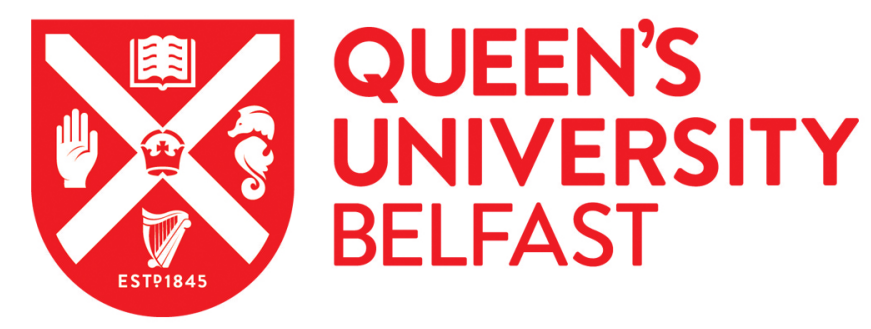

\title{
Abortion and Reproduction in Ireland: Shame, Nation-building and the Affective Politics of Place
}

Fischer, C. (2019). Abortion and Reproduction in Ireland: Shame, Nation-building and the Affective Politics of Place. Feminist Review, 122(1), 32-48. https://doi.org/10.1177/0141778919850003

\author{
Published in: \\ Feminist Review
}

Document Version:

Peer reviewed version

Queen's University Belfast - Research Portal:

Link to publication record in Queen's University Belfast Research Portal

Publisher rights

Copyright 2019 SAGE. This work is made available online in accordance with the publisher's policies. Please refer to any applicable terms of use of the publisher.

\section{General rights}

Copyright for the publications made accessible via the Queen's University Belfast Research Portal is retained by the author(s) and / or other copyright owners and it is a condition of accessing these publications that users recognise and abide by the legal requirements associated with these rights.

Take down policy

The Research Portal is Queen's institutional repository that provides access to Queen's research output. Every effort has been made to ensure that content in the Research Portal does not infringe any person's rights, or applicable UK laws. If you discover content in the Research Portal that you believe breaches copyright or violates any law, please contact openaccess@qub.ac.uk. 


\section{Abortion and Reproduction in Ireland: Shame, Nation-Building, and the Affective Politics of Place}

\section{Clara Fischer}

[This article was published in Feminist Review, Vol. 122, No. 2, 2019, pp. 32-48]

In 2018, Irish citizens voted overwhelmingly to repeal the $8^{\text {th }}$ Amendment to the Constitution to allow for the introduction of a more liberal abortion law. In this article I develop a retrospective reading of the stubborn persistence of the denial of reproductive rights to women in Ireland over the decades. I argue that the ban's severity and longevity is rooted in deep-seated, affective attachments that formed part of processes of postcolonial nation-building and relied on shame and the construction of the Irish nation as a particular, gendered place. The article develops the notion of "gendered displacement" to conceptualise abortion travel in the context of the history of women's coercive confinement, and provides an affective, feminist reading of the interlinkages between place and nationhood. It also draws on three cases - the $X, Y$, and $Z$ cases - to illustrate the centrality of place and women's occupation of space to the analysis of Ireland's abortion ban, which should be read in the wider context of the legacy of what I term the affective politics of place.

"Emotion - etymology: from Latin emovēre, to remove, displace" (Merriam-Webster)

"The shame factor...having to lie to everyone...the lies and the shame make you feel like you're doing something really wrong" - Sarah B in interview with Human Rights Watch, 2008 (Human Rights Watch 2010)

"It was just this...overwhelming feeling of being...shunned, and of being exiled, and of being pushed away... having to do this secret thing in a different country and I couldn't tell anybody" - Anonymous in Journey (Byrne 2017)

What is the relationship between nations as territories and the symbolic value women are afforded in national imaginaries? How are nations conceived as places through gendered, affective investments? In this paper, I will explore these questions by examining the stubborn persistence of the denial of reproductive rights to women in Ireland over the decades by arguing that deep-seated, affective attachments formed part of processes of postcolonial nation-building that relied on shame and the construction of the Irish nation as a particular, gendered place. While Irish citizens voted, in May 2018, overwhelmingly in favour of a repeal of the $8^{\text {th }}$ Amendment to the Constitution to allow for the introduction of a more liberal abortion law, this essay assesses the uniqueness of the abortion ban in Ireland, which was anachronistic in terms of its severity - allowing for abortions only in cases where a woman's life was at risk - and its longevity. Although attitudes to reproduction and sexuality in Ireland have clearly changed owing to a number of factors, including a very successful feminist campaign waged for abortion law reform, I will be outlining, in what follows, the specific construction of women as bearers of the nations' virtue, the risks transgressive women posed to this especially in terms of sexuality and reproduction, and the methods used by Church and State to respond to such risks. Specifically, I 
will be arguing that the Irish nation - conceived of as exceptionally morally, sexually pure - had to be maintained, and that this issued in the physical excising of women's bodies, either in institutions, or through effective removal to other jurisdictions for abortion access.

Nations are, in Anderson's famous formulation, "imagined communities," but these are also mapped onto geographical, national territories to construct nations as particular places. I will be asking, in this essay, what kind of place Ireland was until recently? What kind of constructions of Ireland predominated in the national imaginary and how did this impact on reproductive rights? To examine the specifically gendered implications of such constructions, I will be developing the notion of "gendered displacement" in terms of abortion travel and institutionalisation, and will provide an affective, feminist reading of the interlinkages between place and nationhood. I will also draw on three cases - the X, Y, and Z cases - to illustrate the centrality of place to the analysis of Ireland's now historic abortion ban, which should be read in the wider context of the legacy of gendered nation-building, as transgressive women's occupation of space was problematised within a particular conception of Irish nationhood.

Ireland's recent, unexpected referendum result, which saw two thirds of the electorate vote to repeal the $8^{\text {th }}$ Amendment to the Constitution to usher in a more liberal abortion regime, certainly spells a sea change in Irish social policy. However, my retrospective analysis of the now reformed abortion ban will shed light on the uniqueness of Ireland's abortion regime by drawing out the role of gendered shame and women's occupation of place in Irish, postcolonial nation-building. As such, it may illuminate both the significant changes on matters of reproduction and sexuality indicated by the results of the referendum vote, as well as the potential, continued purchase of gendered shame and the notion of place in the national imaginary of a post-repeal Ireland. Moreover, by theorising the long-standing circumscription of women's occupation of space and women's freedom of movement in Ireland through the development of "gendered displacement" in the context of an "affective politics of place," I hope to add concepts that might be useful for an examination of the relationship between shame, place, and nationhood in other contexts, particularly where women are similarly forced to travel for access to abortion services or are institutionalised. ${ }^{1}$ By examining place in terms of the construction of the Irish nation as a particular, gendered place, and the removal of transgressive women therefrom, this article also explores an underappreciated aspect of shame, which, as I argue here, centres on that intrinsic device of the shame experience - hiding - to issue in the physical excising of women's bodies.

\section{Three cases: X, Y, Z}

In 1992, the Irish High Court issued an injunction against a girl to prevent her from travelling to the U.K. to seek an abortion. The girl was pregnant as a result of rape by an adult family friend. She was effectively confined within the boundaries of the Irish state, but eventually a Supreme Court ruling lifted the injunction on the basis of the threat to her life posed by her suicidality and positively affirmed X's constitutional right to life. The $\mathrm{X}$ case ruling, as it became known, had wide-reaching consequences

\footnotetext{
${ }^{1}$ Freeman, for example, has written about border crossings by women from Chile to Peru to access abortion services - see Cordelia Freeman, "The Crime of Choice: Abortion Border Crossings from Chile to Peru," Gender, Place \& Culture: A Journal of Feminist Geography 24, no. 6 (2017).
} 
for women in Ireland, raising concerns about legislative guidance on a previously introduced constitutional amendment designed to copper-fasten Ireland's antiabortion stance (the $8^{\text {th }}$ Amendment) that enshrined the right to life of the "unborn" and equated this to the right to life of the mother. ${ }^{2}$ The $\mathrm{X}$ case brought to light the role of suicidality in the context of to the right to life and raised related legal questions on women's right to travel and to information. Twenty-one years later, and after several highly publicized tragedies - including the recent death of Savita Halappanavar, who was denied an abortion in an Irish hospital despite already experiencing a miscarriage - the Protection of Life During Pregnancy Act 2013 (PLDPA) was adopted. It was prompted by a European Court of Human Rights judgement, which identified an "absence of any implementing legislative or regulatory regime" on abortion, and was set to redress what was termed by one of the X case Supreme Court judges an "inexcusable" lack of legislative guidance around the issue of abortion in Ireland. ${ }^{4}$ As such, the PLDPA theoretically made provision, however cumbersome, for the protection of a pregnant woman's life (as distinct from her health), including in cases of a threat to her life by suicide. ${ }^{5}$ The upshot of this was that a woman in Ireland was, until recently, only entitled to an abortion in cases where there was "a real and substantial risk of loss of the woman's life," extending to risk "by way of suicide" (Protection of Life During Pregnancy Act 2013). Just a few months after the adoption of the 2013 PLDPA news emerged of a case that highlighted similar issues to those previously raised by the X case, and supposedly addressed by the PLDPA.

In 2014, it was reported that Ms. Y had been persecuted and raped in her country of origin, and discovered that she was pregnant while undergoing the asylum process in Ireland. She repeatedly stated, to several agencies, including to the Irish health service (HSE), that she wanted to have a termination or would otherwise commit suicide. Following several delays, it seems that in the end, she was voluntarily, but nonetheless under (subtle) coercion, held in an Irish hospital until the foetus was viable and delivered by Caesarean section. ${ }^{6}$ Her child was taken into state care, and

\footnotetext{
${ }^{2}$ The $8^{\text {th }}$ Amendment, or article 40.3 .3 of the constitution, was introduced by referendum in 1983 and states that the "state acknowledges the right to life of the unborn and, with due regard to the equal right to the life of the mother, guarantees in its laws to respect, and, as far as practicable, by its laws to defend and vindicate that right" - Constitution of Ireland - Bunreacht na hÉireann (2015).

${ }^{3}$ In a rebuke to legislators, Justice J. McCarthy pointed out that the State's failure to legislate since the introduction of the $8^{\text {th }}$ Amendment nine years previous, was "no longer just unfortunate" but "inexcusable" - see "Timeline: The Referendums, the X Case and European Court Challenges," 2010. ${ }^{4}$ European Court of Human Rights, Case of A, B and C v. Ireland (2010), §267. This judgment led to the establishment of an expert group by the government, to advise it on implementation of the judgement. The PLDPA was therefore also a response to the A, B, and C v Ireland ruling. ${ }^{5}$ As feminist activists, medics, and legislators pointed out during the debate on the introduction of the PLDPA, women whose lives are at risk from suicide are likely to experience the "test" of suicidality set out in the Act as extremely prohibitive and invasive. The PLDPA requires a woman to have suicidality certified by three medical practitioners (one obstetrician and two psychiatrists, preferably in consultation with the woman's GP), but may be seen by even further practitioners in the case of conscientious objection or if certification is refused and a review requested (which the woman must do herself in writing) (see Protection of Life During Pregnancy Act 2013, and Amnesty International 2015).

${ }^{6}$ Since this is an ongoing legal case, there is limited information available to the public. However, details of a preliminary HSE inquiry were reported (which need to be approached with caution, given Ms. Y's apparent exclusion from this process), and Ms. Y's lawyer has revealed information to the press and to Amnesty International (see Holland 2014; Amnesty International 2016; The Irish Times 2015)
} 
she is currently suing the state for false imprisonment, assault, and battery, among other charges (The Irish Times 2016). More recently still, another case emerged of a pregnant, apparently suicidal minor. She was examined by a consultant psychiatrist who established that she was "at risk of self harm and suicide as a result of the pregnancy," but found that abortion "was not the solution for all of the child's problems at that stage" (Child Care Law Reporting Project 2017). While the girl and her mother thought they were being transferred to Dublin for a termination, they discovered that the girl was actually being sectioned in a mental health facility with an order obtained under the Mental Health Act on the strength of the psychiatrist's evidence. News of this latter case came to light via a project on child care cases in the Irish courts, which also revealed that the order was later discharged, following a diagnosis of not having a mental illness and thereby no longer being subject to the Mental Health Act. ${ }^{7}$

These latter two, recent stories of women in distressing and vulnerable situations clearly indicate that the pre-repeal legal framework on abortion - the $8^{\text {th }}$ Amendment of the Constitution, with its equivalence between a woman's and a foetus's right to life, and the PLDPA, with its provision for suicidality - was dysfunctional and failing women, even in scenarios that seemed, specifically, to fall within the remit of the PLDPA. Suicidality featured in both cases, and yet, Ms. Y did not receive the repeatedly requested termination she should have been entitled to under the PLDPA, nor did Ms. Z (as I shall refer to the anonymous person of the latter case), who was instead sectioned. ${ }^{8}$ As consultant psychiatrist, Prof. Veronica O'Keane, succinctly put it at the time: access to a termination under the terms of the PLDPA was simply a "lottery" (Holland 2017). Morevoer, access was also, as evinced by Y's status as an asylum seeker and Z's as a minor, impacted by other forms of marginalisation.

Taken together, the $\mathrm{X}, \mathrm{Y}$, and $\mathrm{Z}$ cases are instructive for an analysis of Ireland's abortion ban. My reading here will not be concerned with the obvious dysfunctionality of the legal framework, which Irish voters clearly recognised and rejected in the recent referendum. I will, though, be focusing on the recurring issue of "place" and related themes, and will return to the spatial circumscription of X, Y, and Z. My analysis will explore the gendered assumptions and affective attachments underpinning Ireland's pre-repeal abortion law to tease out such recurring themes to examine the longevity and severity of the Irish abortion ban, and to see what relevance - if any - these themes may have to social policies and the national imaginary of a post-repeal Ireland. I will be focusing, particularly, on the assumed permissibility (by the state) to circumscribe women's freedom of movement, and will be arguing that this is deeply rooted in Ireland's history as a postcolonial nation-state. As such, I will be making linkages between Ireland's historic mass-confinement of

\footnotetext{
${ }^{7}$ Again, further details on this case are largely lacking beyond what has been recorded by the Child Care Law Reporting Project. However, as will become evident, my analysis is not intended to present a detailed narrative of the events of these cases, but rather to highlight some common themes - themes that are also evinced by other cases beyond those focused upon here - to enable a wider discussion on abortion and the affective politics of place in Ireland. The reason for choosing these particular cases is their very recent nature, and the light they may shed on contemporary legislative and policy change. ${ }^{8}$ Given the limited available information from the Child Care Law Reporting Project, and the comparatively scant publicity this case has garnered, the girl at the centre of these events has not yet been given an anonymous title. My attributing 'Ms. Z' to her is simply to act as a consistent shorthand to facilitate easier discussion of the case, and should not be confused with the 'Ms. $Z$ ' from a recent surrogacy case (see Lynch, 2014).
} 
women in Magdalen laundries and similar institutions, and will highlight some dominant motifs in a discussion of the $\mathrm{X}, \mathrm{Y}$ and $\mathrm{Z}$ cases that connect Ireland's past treatment of women in the context of reproduction and sexuality to the present. My analysis of Ireland's politics of place, moreover, will also highlight a thus far unacknowledged affective dimension of same, ${ }^{9}$ thereby problematising women's occupation of place, via the history of women's coercive confinement in Ireland and the mobilisation of gendered shame as it plays out in the ongoing project of Irish nation-building. The article will thus contribute to the literature on gender and nationalism, ${ }^{10}$ specifically in an Irish context, and to the important body of work on abortion in Ireland. ${ }^{11}$ Additionally, it will uniquely develop an analysis of the affective politics of place, engaging with feminist work on affect and emotion by exploring how emotions, specifically shame, might structure gendered spaces. ${ }^{12}$

\section{Reproduction and Gendered Irish Nation-Building}

In her important study on the X case in Ireland, Abortion and Nation, Lisa Smyth ties the historic, Irish abortion ban to notions of Irish national identity (Smyth, 2005). She mentions that the Pro-Life Amendment Campaign (PLAC), waged by anti-choice advocates to successfully introduce the $8^{\text {th }}$ Amendment to the Constitution in 1983, saw itself as the original identifier of the threat posed by liberal encroachment on matters of sexuality and reproduction, ${ }^{13}$ and initiated a pre-emptive crusade to keep such encroachment out of Ireland. ${ }^{14}$ As such, she notes that a "group of moral entrepreneurs" were to be credited with successfully "defining abortion as a threat to the nation's character" (Smyth 2005, 55). Indeed, Smyth's depiction of a conservative, moralising discourse promoted by people seeking to keep Ireland's virtuous character intact, is an apt description of the political theatre staged for the purposes of the amendment, however, I maintain that this runs much deeper and beyond the specific case of abortion and the PLAC in Ireland.

Situating the PLAC campaign in terms of the creation of a moral panic, Smyth notes that "it is difficult to pinpoint any particular event, or series, of events in Irish abortion politics, which could be characteristic of the first stage" - the first stage of a moral panic being described as typically involving a key event that elicits intense media scrutiny (55-56). This lack of a decisive event that may have spurred the 1980s hysteria of the supposed threat of abortion can be attributed to the fact that the PLAC built on decades' worth of moralistic discourse and scaremongering on matters of

\footnotetext{
${ }^{9}$ While Lisa Smyth has also discussed shame in the context of the Irish abortion ban, she does not examine this in relation to women's occupation of place, and the historic mass-institutionalisation of women; nor does Smyth assess the ontological structure of shame and the centrality its mechanism of hiding has played in the Irish state's policy approach to reproduction and sexuality (see Smyth, 2015).

${ }^{10}$ For notable examples, see Yuval-Davis, 1998, and McClintock, 1993.

${ }^{11}$ There is a large literature on this topic - see e.g. Bacik, 2015; Smyth, A., 2015; Quilty et al, 2015; and McAvoy, 2013.

12 For work on affect and emotion, see Koivunen, 2010; Meyers, 1997; Hemmings, 2005; and Pedwell and Whitehead, 2012. For work on shame, see Fischer, 2016, 2017, and 2018; Nussbaum, 2004; and Locke 2016.

${ }^{13}$ Both Roe v. Wade in the U.S. and McGee v. Attorney General in Ireland caused conservative campaigners anxiety, with the latter case allowing married couples to import contraception for personal use.

${ }^{14}$ Abortion was already prohibited in Ireland under sections 58 and 59 of the Offences Against the Person Act. The PLAC was undertaken to make absolutely sure abortion wouldn't be legalized in Ireland by seeking a constitutional guarantee for the ban (see Offences Against the Person Act, 1861).
} 
sexuality, reproduction, and gendered embodiment in Ireland. Smyth identifies "clergy, medical practitioners, theologians, and members of grassroots organizations" as the "moral entrepreneurs" ushering in panic on abortion and the alleged, pressing need for a constitutional amendment to secure Ireland against abortion's dangers. Very similar thinking by the same proponents, however, also underpinned whole swathes of social policy, itself heavily influenced by the Catholic Church, at least since the foundation of the Irish state.

As Fischer has argued, a conservative, moralistic approach to reproduction and sexuality was, from the beginning, intimately intertwined with ideas of Irishness, as women were constructed as bearers of the nation's honour (Fischer 2016). PostIndependence, the project of Irish nation-building thus relied heavily on the assumed - and formally enforced - moral and sexual purity of Irish women, as the national imaginary needed to satisfy demands for the superior virtue of the Irish when compared to the former colonizer. Although the putative threats posed by all kinds of secular, seemingly liberal encroachments deemed to be moral vices (and often described as Anglican and English in nature), were met with strict prohibition or circumscription in the newly formed Irish state, this was particularly the case with matters concerning women's bodies and sexuality. For, the nation's very identity was centred on the superior purity and virtue of Irish women. Threats to this identity, which all women, thanks to their assumed capacity for embodied sinfulness and impurity posed in the first instance, were thus undercut in policies that restricted women's social and public roles, and that physically excised them if they fell short of being worthy symbols of the nation (Fischer 2016). It is for this reason that institutionalisation, the mass-incarceration of women, was so extensively and uniquely relied on in modern Ireland (see Fischer 2016; O'Sullivan and O'Donnell 2012). Irish nation-building used institutionalisation as a way of maintaining a national identity premised on gendered purity and moral superiority by physically removing threats to said identity (Fischer 2016).

Certain "vices," especially pregnancy out of wedlock, were very similarly constructed, right from the early decades of the Irish state, to the construction of abortion as a moral danger in the 1980s, especially as these pertained to the idea of Ireland as a morally superior nation. Indeed, the PLAC, far from initiating its own moral panic out of a specific event, drew on deeply ingrained discourses of Irishness that, for decades, had presented women's sexuality and bodies as problematic, potentially sinful, and in need of control, lest the nation's very identity be put at risk. The PLAC therefore drew on the same tropes of English sinfulness and the paranoid depictions of women's collusion with the former coloniser. Fletcher notes that a prominent anti-abortion poster during the PLAC campaign had the slogan: "The Abortion Mills of England Grind Irish Babies into Blood that Cries out to Heaven for Vengeance'," and reads this as presenting abortion as a colonial "weapon that England uses against Ireland" (Fletcher 2001, 577). Similarly, Smyth highlights the "right wing's narrative of nationhood," which, during the campaign, "likened" the (invariably male) "vulnerable foetus" to the "vulnerable nation" and depicted feminists as "having both an economic and colonial interest in securing access to abortion for Irish women" (Smyth 2005, 66). Drawing such equivalences between abortion, Englishness, and colonial oppression served the purpose of defining Irishness in strictly moralistic terms, that is, in terms that maintained the decades-long project of premising Irish identity on women's superior virtue and purity. 
In what follows, I want to explore this phenomenon of Irish identity-formation (which, as I have set out, dates right back to the foundations of the Irish state), in its relation to gender, reproduction and abortion, but in the context of wider issues related to place and emotion. As I've already explained, one way of dealing with perceived transgressions of women's symbolic role as bearers of Irish, national purity was to physically remove them and contain them in institutions. The Irish state and the religious orders running these institutions thus participated in a politics of place that forcibly excised women in order to keep intact this fiction of a morally and sexually pure Ireland. Similarities arise here in terms of the (auto)removal of Irish women forced, over the decades, to make the journey to seek abortions in England. While many women simply can not travel, those who did were exercising a certain agency within tight constraints, as the prohibition of abortion in Ireland compelled women to access health care in another jurisdiction - often that of the former colonial power - and served the function of ensuring that Ireland could continue to present itself as a morally pure nation, unsullied by the sinfulness and presumed-to-be morally questionable practice of abortion. In this sense, then, the gendered circumscription of place allowed the territory of Ireland to be conceived in the image of a morally superior nation, as, for generations, the national scene neatly excised the transgressive bodies of women - be those women who became pregnant out of wedlock or women seeking terminations. ${ }^{15}$

\section{Abortion, Ireland's Politics of Place, and Gendered Displacement}

The $\mathrm{X}$ case centred on a child victim of rape, who was forced by the Irish state into lock-down. She was effectively imprisoned within the borders of the Irish Republic by an injunction prohibiting her from travelling to the U.K. in search of a termination. Despite the eventual lifting of the injunction on the basis of X's suicidality, the case raised serious issues with regard to women's freedom of movement and the Irish state's power to restrict same. Following the injunction, the question arose whether "women could now face physical examination at air and sea ports, as they tried to leave the country" (Smyth, 2005, 112) - was it possible that any woman, under the suspicion of being pregnant and trying to access abortion services abroad, could now be inspected and contained within the bounds of the nation-state, like $\mathrm{X}$ and her family had been? This worry remained even after the Supreme Court issued its ruling countermanding the injunction, as the right to travel was, in fact, not found to be absolute (6). In the wake of such concerns, and in an effort to undo even the limited permissibility of abortion on the ground of suicidality, the Irish government thus put three proposals to the people in referenda to amend Article 40.3.3 to the Constitution (the $8^{\text {th }}$ Amendment): the first was a proposal to allow for abortion only in cases of risk to life of the woman, excluding suicide - an effective roll-back from the $\mathrm{X}$ case ruling; the second was a guarantee of the right to travel; and the third, a protection of the right to information on services that are legal in other jurisdictions. The first amendment was rejected, while the latter two were carried (Bacik 2015, 158). This meant that women could have abortions on the basis of threat to life, including,

\footnotetext{
${ }^{15}$ Although theoretically reserved for women who became pregnant out of wedlock, Irish institutions, such as the Magdalen Laundries, became repositories for women on all kinds of different, arbitrary grounds (Fischer, 2016; Irish Government 2013). Moreover, these groups of women are of course not mutually exclusive, and as I will set out below, have been treated as part and parcel of a feminized threat to the nation.
} 
theoretically, from suicide, and again, theoretically at least, ${ }^{16}$ were entitled to information on abortion services elsewhere, and permitted to travel to access such services abroad.

In the end, the $\mathrm{X}$ case ruling, and the protection of the right to travel and to information, enshrined the oft-cited, contradictory "Irish solution to the Irish problem" of abortion. It removed women in need of abortions from the island of Ireland (except in cases of risk to life, including suicide), ${ }^{17}$ thereby maintaining the integrity of an abortion-free nation of utmost virtue, while, at the same time, accepting women's travel to other jurisdictions, primarily to the former coloniser. Travel, and the ability of Irish women to access services elsewhere, thus became a safety valve for an Irish national identity premised on exceptional moral purity. ${ }^{18}$ In a politics of place that continued to draw on representations of Ireland as a morally superior nation, the "problem" of the occupation of space within Irish territory by women needing terminations was thus "solved" by the accepted, physical removal of their bodies from Ireland.

This policy approach, which until recently defined women's abortion access and was tightly intertwined with ideas of Irish nationhood, was manifested in what has come to be known as the Irish "abortion trail." The term usually refers to the long-standing pattern of travel by women from Ireland to other jurisdictions, particularly to England, to seek access to abortion services there. Eithne Luibhéid $(2006,65)$ also titles this movement of women from Ireland across borders "abortion migration," with its own history that spans the better part of the twentieth century. Other commentators have variously described the phenomenon as "exile" (a term emphasising the coercive nature of having to travel, and used by activists such as the X-ile project), ${ }^{19}$ "temporary emigration" [Murphy-Lawless $(1993,62)$ notes that Irish abortion travelling is recorded as such in Britain's official statistics], and "abortion tourism" (Gilmartin and White 2011, 276).

While each of these terms emphasises a particular aspect of the forced journeys Irish women have had to make to access abortion services abroad, they also, on the other hand, miss the mark of the exact meaning entailed by such travel. For instance, Gilmartin and White already point to the fact that "tourism" usually has connotations of "agency, choice, and possibility" (276), with "migration" and "emigration" similarly failing to explicitly highlight the coercive nature of the journeys made by women experiencing crisis pregnancies. While the term "exile" does, in fact, capture this forced aspect of women's travelling for abortions, it does not correspond to the

\footnotetext{
${ }^{16}$ Bacik notes that despite this, an early study showed that women and girls had difficulty accessing information on abortion and contraception $(2015,158)$.

${ }^{17}$ While thus excising women by forcing them to travel, there were and are of course women who cannot travel, and who have, for example, used abortion pills themselves. Nonetheless, the official position of the Republic of Ireland was still one of an abortion-free nation-state. Moreover, despite the different historical trajectory of Northern Ireland, with distinct implications for the forging of national identities, the North has also witnessed a staunch, conservative opposition to abortion, hence my reference to the whole "island of Ireland." For work on the Northern Irish context, see Smyth 2006, and O'Rourke 2016.

${ }^{18}$ It's important to note that emigration, more generally, acted as a kind of safety valve over the decades - for work on this in relation to gender, see Ryan (2002).

${ }^{19}$ This project was set up to provide a gallery of faces to render women who've accessed abortion services outside of Ireland and Northern Ireland visible - see http://www.x-ileproject.com.
} 
usual definition of exiles as "individuals or families who have been part of political struggles in the homeland," and who are living abroad and "aim to 'go back' the moment the political situation changes" (Yuval-Davis 1998, 18). There are, undoubtedly, women who have left Ireland to set up lives elsewhere in response to Ireland's patriarchal social policies - the emigration of women who were once institutionalised being an obvious example - however, such long-term residence elsewhere is different from the temporary travel undertaken specifically to access abortion services. Moreover, not all women seeking abortions abroad will have been involved in political struggles at home, although all women, regardless of political persuasion, were of course subject to Ireland's abortion ban.

Given that Ireland's policy stance on abortion was entangled with the development of a national identity centred on the moral purity of women, and given that this entailed the construction of Ireland as a place - an imagined, but also physical, national territory free from moral vice - the issue of women's travel arose as part of a politics of place that effectively denied transgressive women a place - both physically and symbolically - within Ireland. As such, women's abortion journeys can be described as being characteristic of a kind of gendered dis-placement - that is, following a common definition of 'displacement,' they constitute the "moving [of] something" in this context women in Ireland - "from [their] place or position." ${ }^{20}$ Gendered displacement emphasises the coercive nature of women's travel to seek abortions, but also draws attention to the denial of Ireland as a place for them, in which they may have held a legitimate "place or position" - rather than the place that withheld from women the health services they required; a place that was informed and conflicted by a spurious, definitional notion of feminized purity; and a place that excised, or rather, dis-placed, women deemed to transgress said purity in a denial of their Irishness. Moreover, gendered displacement draws on a related meaning attached to the latter term, as displacement may also refer to the "enforced departure of people from their homes" (Oxford English Dictionary) not, in this case, because of war or persecution, but rather in response to gendered policy-making that identified Ireland - home - as a place where abortions did not happen, and forced women to leave their home country in search of abortion services abroad. Not only, then, did Ireland's gendered displacement identify women seeking abortions as illegitimate subjects of the Irish nation-state and, accordingly, removed them from Irish territory, but, through this symbolic and physical removal, it also induced a strong sense of women's alienation from Ireland, from their home. ${ }^{21}$

\section{Shame and Ireland's Affective Politics of Place}

Indeed, women who've experienced gendered displacement by having to travel to access abortion services elsewhere, have widely reported feeling "shunned," "exiled," "pushed away," "like an outcast" (Anonymous in Byrne 2017, 2:50mins and $4: 55 \mathrm{mins}$ ). Since their needs were not catered for in their home country, they were forced to undertake this arduous journey from Ireland, the home from which they felt rejected. As one woman describes it, it is "this feeling of being let down by this place that I've grown up in, this country that I love - I love Ireland. And I feel like I have to

\footnotetext{
${ }^{20}$ The Oxford English Dictionary definition reads as follows: "Displacement: The action of moving something from its place or position." - see https:/en.oxforddictionaries.com/definition/displacement

${ }^{21}$ This connection to forced movement from one's home is also aptly captured by a recent art installation titled 'Not at Home' designed to "recreate the experience of the 170,000 Irish women who have travelled abroad for abortions"(see Ingle 2017).
} 
get across this huge body of water to be treated... as a human being" (4mins). In addition to such feelings of hurt, anger, disappointment, and loneliness, many women also relate feelings of shame. As part of her testimony to the Citizens' Assembly, ${ }^{22}$ for instance, a woman who had had an abortion in Liverpool, explained that "even though you know you are doing the right thing, you are still ashamed" (McGreevy 2017). Similarly, an anonymous interviewee for a Human Rights Watch Report on abortion in Ireland noted that the "shame factor" and "the lies" meant that she felt as though she was doing something "really wrong" (Human Rights Watch 2010, 45). Notably, a United Nation ruling that, for the first time established the Irish criminalisation of abortion as a violation of a woman's human rights, referred to the "shame and stigma" caused by such criminalisation in a land-mark hearing of Amanda Mellet's case (Amnesty International Ireland 2016). I maintain that such mobilisation of shame by the Irish state is central to gendered displacement and Ireland's politics of place.

As Fischer has shown with regard to the containment of women in Magdalen laundries, there is a co-constitutive relationship between the gendered politics of shame and women's occupation of place. ${ }^{23}$ Since shame involves the assumption of a moral failing, and the need to cover same, the physical hiding of women - constructed as shameful moral failures incapable of living up to the standards of sexual purity required of them as symbols of the nation - replicates an essential feature of shame: that is, an intense need to cover in light of a fear of exposure. Shame is usually conceptualised as a painful, and all-encompassing emotion that is experienced in relation to one's perceived failure to live up to certain standards, and thus implies a deep-seated moral shortcoming that cannot simply be amended through restorative action. Shame, especially when compared to guilt, has something to say about our character, about the very person we are. In the shame experience, we are afraid of shattering other people's perceptions of us and are scared of their reaction to our failure, should this ever be revealed. This is why shame usually involves the obsessive hiding of said failure in order to maintain one's sense of being seen in a certain light, and to preserve one's relationships. ${ }^{24}$ As Fischer sees it, the hiding of women in institutions in modern Ireland is reflective of their designation as shameful Others who need to be excised in the national imaginary to preserve a national identity premised on superior moral virtue. Transgressive women, that is, those who become pregnant out of wedlock or are in some other sense deemed threatening, are constructed as shameful and therefore in need of hiding (Fischer 2016).

In much the same way, the case can be made that women in need of terminations - to again preserve Ireland's identity as a morally superior nation that did not allow the allegedly sinful practice of abortion within its territory - were constructed as shameful and therefore hidden (that is, removed) to have terminations elsewhere. As noted, this removal served the function of maintaining Ireland as an abortion-free realm that could continue its claim to moral superiority, as it displaced women

\footnotetext{
${ }^{22}$ The Citizen's Assembly constituted a deliberative process made up of 99 citizens and a chairperson, which found in 2017 - after extensive hearings with legal and medical experts and advocates, among others, as well as a public submission process - that Ireland's legal framework on abortion should be overhauled through repeal of the $8^{\text {th }}$ Amendment to the Constitution (with abortion in future to be legislated for by the Oireachtas, the Irish parliament) - see Citizen's Assembly 2017.

${ }^{23}$ Clara Fischer, "Gender, Nation, and the Politics of Shame: Magdalen Laundries and the Institutionalisation of Feminine Transgression in Modern Ireland," Signs: Journal of Women in Culture and Society 41, no. 4 (2016): 821-43.

${ }^{24}$ For more on shame, see Ahmed 2004, and Nussbaum 2004.
} 
needing abortions. Shame played a central role in this, as shamed national subjects were effectively banished via gendered displacement, thereby, again, enacting that typical mechanism of shame: hiding. My contention, then, is, that in both cases - the mass-institutionalisation of women and the gendered displacement of women seeking abortions - there was at work a politics of shame and of place. Shame became a mechanism through which women were afforded - or indeed, not afforded $-\mathrm{a}$ particular place within the Irish national imaginary, but also within the physical territory of Ireland. Women's occupation of place within the Irish nation was dependent upon their fulfilment of a symbolic role of superior feminine purity, and threats to that purity - especially of the sexual and embodied variety - were presented as shameful, thereby legitimating the physical removal of transgressing women, be it to Magdalen laundries within Ireland or to abortion clinics on the other side of the Irish border. In short, Ireland's gendered politics of place was inherently an affective politics premised on shame.

To be sure, there are women in Ireland who say that they do not feel shame at having had an abortion and, in fact, most women speak of relief as the primary feeling following the procedure (see The Irish Times 2017). However, my claim is not that shame is universally experienced by women having abortions, but rather that the historic policy approach to abortion in Ireland has relied on constructions of abortion and of women needing abortions as shameful and as threatening to a national identity of feminine sexual purity. This construction is felt by women who have been forced to travel abroad in search of abortions, as the Irish criminalisation of abortion, and the surreptitious nature of the journey and its planning - that is, the hiding, which is of course a feature of the politics of shame and place - necessitated secrecy and silence. ${ }^{25}$ Women who have made the journey thus speak of the burden this secrecy, and the pressure to keep a (shameful) secret imposes on them, with one woman stating that she experienced her abortion as "this secret thing in a different country and I couldn't tell anybody" (Anonymous in Byrne, 2017, 2:50mins). Shame, therefore, was utilised in Ireland's affective politics of place to displace women either externally in search of terminations abroad, or internally, through containment in institutions.

\section{Recurring Themes in the Affective Politics of Place}

The etymology of the word 'emotion' aptly captures the entanglement of physical movement with feeling. The term comes from the Latin, emovere, meaning to remove, displace - which, in an Irish context reflects the physical and affective removal and displacement of women, via the mobilisation of shame against gendered Others in Ireland's affective politics of place. ${ }^{26}$ Shame, and the construction of transgressive women as shameful, does the work of displacing by ensuring the permissibility of circumscribing women's place within, or indeed, outwith, the Irish nation. Worryingly, the cases detailed at the beginning of this essay, display a remarkable recurrence of themes that are the result of this long and sorry history of Ireland's affective politics of place, which has witnessed, time and time again, the

\footnotetext{
${ }^{25}$ With that said, there have been some important recent examples of activists breaking this silence by going public with their abortion stories, including the contributors to the X-ile project already noted, as well as the women behind the @ TwoWomenTravel Twitter handle, who live tweeted their abortion journey in 2016 (see D'Arcy and Ruxton 2016).

${ }^{26}$ See Merriam-Webster: https://www.merriam-webster.com/dictionary/emotion
} 
displacement and forcible containment of women. Far from being restricted to cases of abortion, there was, in Ireland, precedent for the state's limiting of women's freedom of movement and the proscription of certain places specifically to deal with matters of transgressive women's bodies and matters of reproduction, notably Magdalen Laundries and Mother and Baby Homes. ${ }^{27}$

The permissibility of displacing and detaining women was one that arose in the context of Irish national identity-formation in the early decades of the Irish state, which established the legitimacy of the state to strongly intervene and control women's bodies and sexuality in a bid to protect and promote a specific version of Irishness. I maintain that the ease with which displacement - internally (in institutions) or externally (via the abortion trail) - was, until recently, practiced, threatened, institutionalised as a legitimate policy stance and approach to reproduction, is due to this history of the continuous problematisation of reproduction and sexuality in Ireland and the forcible movement and detaining of women as a common and widespread response to such problematisation. The $\mathrm{X}, \mathrm{Y}$, and $\mathrm{Z}$ cases highlight the coercive circumscription of place for each of the women involved: $X$ was interned within the Republic's borders and prohibited from travelling to the U.K.; $\mathrm{Y}$ was kept in a hospital to give birth; and $\mathrm{Z}$, rather than receiving a termination as she requested, was sectioned in a mental health facility. Some of the reported details on Y's treatment, moreover, point to detention being used as a means to pursue a particular ideological agenda. According to Ms. Y's solicitor, contemporaneous medical records showed that her medical team wanted to detain her until the foetus was viable, stating that "we will have to make her an involuntary patient and keep her against her will" (Sheehan 2017). Moreover, on realising that she was not going to receive a termination, Ms. Y wanted to "go home to "end it", to which she was told that "if she attempts this she will have to be detained under mental health legislation" (Holland 2014). Similarly, Ms. Z was forcibly held, under the Mental Health Act, in a mental health institution, again, despite expressing her wish for an abortion.

Although details for both of these cases are sparse, given the need to preserve anonymity and the fact that there are ongoing legal proceedings in Ms. Y's case, they demonstrate the role place and women's occupation of place play in policies that have, for decades, employed the limiting of women's movement and displacement as entirely legitimate mechanisms. As noted, in Ireland this was also affectively informed, via the strong mobilisation of shame, and seems to be borne out in Ms. Y's case. Her solicitor reported that Ms. Y was questioned on her religious beliefs, and asked "whether her baby "deserved a life"," which, according to the solicitor, was supposed to make her client feel "guilty and ashamed" (Sheehan 2017). The affective politics of place thus appears to be recently operational in contemporary Ireland, as the $\mathrm{Y}$ and $\mathrm{Z}$ cases occurred only in 2014 and 2016 respectively. ${ }^{28}$ Moreover, what has always complicated gendered displacement and women's access to abortion services, has been the inability of certain women to travel abroad. Ms. Y's status as an asylum seeker, for instance, meant that travel to the U.K. was simply not open to her. ${ }^{29}$ The

\footnotetext{
${ }^{27}$ Additionally, abuses within these places were often ignored or downplayed. I am grateful to Mairead Enright for pointing this out in her reading of an earlier draft of this paper.

${ }^{28}$ For further details on Ms. Z and the PLDPA, see also Enright, 2017.

${ }^{29}$ It should be noted that there have been important feminist initiatives to support such women, for instance, by the Abortion Support Network, which facilitates women from Ireland accessing abortions abroad - see https://www.asn.org.uk/.
} 
alternative was to somehow illegally procure an abortion in Ireland or to endure forced birthing. The latter seems to have been the case in Ms. Y's story, as she eventually gave birth to a child that was then taken into state care.

By presenting these cases, X, Y, and Z, in the context of Ireland's abortion ban and the wider history of the mass-containment of women in institutions, I've sought to make linkages between Ireland's policy approach to reproduction and sexuality, and to show that there has, since the foundation of the Irish state, been a politics of place at play that drew on shame as a disciplining device to physically and symbolically (re)move women as Irish national subjects. As indicated by the recent referendum, that particular national identity centred on women's moral purity is one that today no longer holds sway as it once did, but, nonetheless, there may be legacy issues in terms of specific policies built to support the once predominant national identity, and the once legitimate use of the gendered, affective curtailment of freedom of movement and prescription of place. The shaming of lone parents, who have borne the brunt of austerity policies in recent years, but are often presented as "free-loaders," is commonplace in Ireland, ${ }^{30}$ and, again, feeds into ideas of gendered nationhood that are extraordinarily reminiscent of previous decades, when women were shamed and institutionalised for being pregnant out of wedlock. The effective choice faced by many single mothers of either being able to parent or to work, given the nonrecognition of lone parents' dual role, also has specific implications in terms of the occupation of place in either the private or the public sphere. While I can, in this paper, only gesture toward the possibility of a lingering of the affective politics of place in contemporary Ireland, it is important to note also the rejection of such a politics by the resounding referendum result to repeal the $8^{\text {th }}$ Amendment.

The task now before feminists is to assess what the future might hold: how may the decades old affective attachments underpinning the politics of place inform - or not new constructions of the Irish nation in a post- $8^{\text {th }}$ Amendment Ireland? What kind of a place is this Ireland now - both in its symbolic and spatial configurations? And what "place or position" are women assumed to occupy therein? There is a strongly conservative backbone in Ireland that still clings to representations of the Irish nation in the traditional, puritanical, gendered terms outlined above. Given the many problematic policy stances arising from such a conception, including the piecemeal provision of sex education and the contemporary disadvantaging of lone parents, feminists need to keep in mind the complex interplay of shame, national identityformation, and place to continue to counter the outgrowths of the affective politics of place, thereby contributing to new national imaginaries for the present.

\section{Acknowledgements}

I would like to thank Máiréad Enright for reading an early draft of this work, and am grateful for comments from the anonymous reviewers and the Feminist Review editors.

\footnotetext{
${ }^{30}$ One Family, "Lone Parents and Shame Survey” (Dublin, 2014).
} 


\section{Funding}

Part of this research was supported by funding from the European Union's Horizon 2020 Research and Innovation Programme under the Marie Skłodowska-Curie grant agreement No 750326 .

\section{REFERENCES}

Ahmed, Sara. 2004. The Cultural Politics of Emotion. Edinburgh: Edinburgh University Press.

Amnesty International. 2017. “Amnesty International/Red C Poll Reveals 60\% Support Access to Abortion on Request," November 1. https://www.amnesty.ie/itstimepoll/ [last accessed 22 December 2017].

—. 2016. "Ms. Y's Case: Denied a Lawful Abortion in Ireland," March 21. https://www.amnesty.ie/ms-ys-case/ [last accessed 22 December 2017].

- 2015. "She Is Not a Criminal: The Impact of Ireland's Abortion Law," http://www.amnestyusa.org/pdfs/Ireland_She_Is_Not_A_Criminal.pdf.

Amnesty International Ireland. 2016. "Ireland's Prohibition and Criminalisation of Abortion Services Violated the Human Rights of a Woman Living in Ireland and Caused Her 'intense Physical and Mental Suffering' according to a GroundBreaking Ruling from the United Nations Human Rights Committ," June 9. https://www.amnesty.ie/un-committee-finds-irelands-abortion-laws-subjectedwoman-cruel-inhuman-treatment/ [last accessed 21 December 2017].

Bacik, Ivana. 2015. "A Feminist Review of the Law on Abortion." In Irish Feminisms: Past, Present and Future, edited by Clara Fischer and Mary McAuliffe, 147-68. Dublin: Arlen House/Syracuse University Press.

Boland, Rosita. 2017. "“FF TD Told Us He Arranged an Abortion for His Niece, but He Was against Abortion."' Irish Times, May 12. https://www.irishtimes.com/life-and-style/people/ff-td-told-us-he-arranged-anabortion-for-his-niece-but-he-was-against-abortion-1.3077115 [last accessed 26 November 2017].

Byrne, Karen. 2017. Journey. https://www.facebook.com/repealproject/videos/1796054314037903/ [last accessed 21 December 2017].

Child Care Law Reporting Project. 2017. "Order Detaining Pregnant Girl Seeking Abortion Discharged," https://www.childlawproject.ie/publications/orderdetaining-pregnant-girl-seeking-abortion-discharged/ [last accessed 25 November 2017].

Citizens' Assembly. 2017. "First Report and Recommendations of the Citizens' Assembly: The Eighth Amendment of the Constitution." Dublin. https://www.citizensassembly.ie/en/The-Eighth-Amendment-of-theConstitution/Final-Report-on-the-Eighth-Amendment-of-the-Constitution/FinalReport-incl-Appendix-A-D.pdf.

Constitution of Ireland - Bunreacht na hÉireann, (2015).

D’Arcy, Ciarán, and Dean Ruxton. 2016. “Two Irish Women Live-Tweet Journey to UK for Abortion." The Irish Times, August 20.

https://www.irishtimes.com/news/ireland/irish-news/two-irish-women-livetweet-journey-to-uk-for-abortion-1.2763194 [last accessed 20 December 2017].

Enright, Mairead. 2017. "Ireland's Failing Abortion Law: Statutory Interpretation, 
Human Rights and Hte Detention of Pregnant Children." Human Rights in Ireland. http://humanrights.ie/uncategorized/irelands-failing-abortion-lawstatutory-interpretation-human-rights-and-the-detention-of-pregnant-children/ [last accessed 22 December 2017].

European Court of Human Rights. Case of A, B and C v. Ireland, (2010). Fischer, Clara. 2016. "Gender, Nation, and the Politics of Shame: Magdalen Laundries and the Institutionalisation of Feminine Transgression in Modern Ireland." Signs: Journal of Women in Culture and Society 41(4), pp.821-43. - 2017. "Revealing Ireland's 'Proper' Heart: Apology, Shame, Nation." Hypatia: A Journal of Feminist Philosophy 32(4), pp. 751-767. . 2018. "Gender and the Politics of Shame: A Twenty-First-Century Feminist Shame Theory." Hypatia: A Journal of Feminist Philosophy 33(3), pp. 371-383.

Freeman, Cordelia. "The Crime of Choice: Abortion Border Crossings from Chile to Peru." Gender, Place \& Culture: A Journal of Feminist Geography 24, no. 6 (2017).

Fletcher, Ruth. 2001. "Post-Colonial Fragments: Representations of Abortion in Irish Law and Politics." Journal of Law and Society 28, no. 4: 568-89.

Gilmartin, Mary, and Allen White. 2011. "Interrogating Medical Tourism: Ireland, Abortion, and Mobility Rights." Signs: Journal of Women in Culture and Society 36(2), pp.275-80.

Government, Inter-Departmental Committe Irish. 2013. "Report of the InterDepartmental Committee to Establish the Facts of State Involvement with the Magdalen Laundries (The McAleese Report)." Dublin.

Hemmings, Clare. 2005. "Invoking Affect: Cultural Theory and the Ontological Turn." Cultural Studies, 19(5), pp.548-567.

Holland, Kitty. 2017. “Accessing Abortion Is a 'lottery' under Irish Rules Psychiatrist." The Irish Times, June 12. https://www.irishtimes.com/news/socialaffairs/accessing-abortion-is-a-lottery-under-irish-rules-psychiatrist-1.3116997 [last accessed 24 November 2017].

_. 2014. "Timeline of Ms Y Case." The Irish Times, October 4. https://www.irishtimes.com/news/social-affairs/timeline-of-ms-y-case1.1951699 [last accessed 24 November 2017].

_ 2012. "Woman 'Denied a Termination' Dies in Hospital." The Irish Times, November 14. http://www.irishtimes.com/news/woman-denied-a-terminationdies-in-hospital-1.551412 [last accessed 24 November 2017].

Human Rights Watch. 2010. "A State of Isolation: Access to Abortion for Women in Ireland.” New York. https://www.hrw.org/report/2010/01/28/stateisolation/access-abortion-women-ireland [last accessed 22 December 2017].

Ingle, Róisin. 2017. "To Understand Abortion Travel, You Have to Be There." The Irish Times, August 28. https://www.irishtimes.com/life-and-style/people/tounderstand-abortion-travel-you-have-to-be-there-1.3198084.

Koivunen, Anu. 2010. "An Affective Turn? Reimagining the Subject of Feminist Theory." In Working with Affect in Feminist Readings: Disturbing Diferences, edited by Marianne Liljestrom and Susanna Paasonen, 8-28. New York: Routledge.

Locke, Jill. 2016. Democracy and the Death of Shame. Cambridge: Cambridge University Press.

Luibhéid, Eithne. 2006. "Sexual Regimes and Migration Controls: Reproducing the Irish Nation-State in Transnational Contexts." Feminist Review, (83), pp.60-78. Lynch, Suzanne. 2014. "Surrogacy No Grounds for Maternity Leave Rules ECJ." The 
Irish Times, March 19. https://www.irishtimes.com/news/socialaffairs/surrogacy-no-grounds-for-maternity-leave-rules-ecj-1.1729834.

McAvoy, Sandra. 2013. "Vindicating Women's Rights in a Fetocentric State: The Longest Irish Journey." In Theory on the Edge: Irish Studies and the Politics of Sexual Difference, pp.39-60. New York: Palgrave MacMillan.

McClintock, Anne. 1993. "Family Feuds: Gender, Nationalism and the Family." Feminist Review (44), pp.61-80.

McGreevy, Ronan. 2017. "Abortion Testimonies: 'They Made Me Feel like My Life Didn't Matter'." The Irish Times, March 4.

Meyers, Diana Tietjens. 1997. "Emotions and Heterodox Moral Perception: An Essay in Moral Social Psychology." In Feminists Rethink the Self, edited by Diana Tietjens Meyers. Boulder, CO: Westview Press.

Murphy-Lawless, Jo. 1993. "Fertility, Bodies and Politics: The Irish Case." Reproductive Health Matters 1(2), pp.53-64.

Nussbaum, Martha C. 2004. Hiding from Humanity: Disgust, Shame, and the Law. Princeton, New Jersey: Princeton University Press.

One Family. "Lone Parents and Shame Survey." Dublin, 2014.

O'Rourke, Catherine. 2016. "Advocating Abortion Rights in Northern Ireland: Local and Global Tensions." Social and Legal Studies 25(6), pp.716-40.

O'Sullivan, Eoin, and Ian O'Donnell. 2012. Coercive Confinement in Ireland: Patients, Prisoners and Penitents. Manchester: Manchester University Press.

Offences Against the Person Act 1861, 1861.

Pedwell, Carolyn, and Anne Whitehead. 2012. "Affecting Feminism: Questions of Feeling in Feminist Theory." Feminist Theory 13(2), pp.115-29.

Protection of Life During Pregnancy Act 2013, 2013. http://www.irishstatutebook.ie/eli/2013/act/35/enacted/en/pdf.

Quilty, Aideen, Sinead Kennedy, and Catherine Conlon, eds. 2015. The Abortion Papers Ireland: Vol. 2. Cork: Cork University Press.

Sheehan, Maeve. 2017. "Solicitor Claims Religious Influence in Ms Y Baby Case." Irish Independent, April 30. https://www.independent.ie/irish-news/solicitorclaims-religious-influence-in-ms-y-baby-case-35666670.html.

Smyth, Ailbhe, ed. 2015. The Abortion Papers Ireland: Vol. 1. Cork: Cork University Press.

Smyth, Lisa. 2005. Abortion and Nation. New York: Routledge, 2005.

- 2015. "Ireland's Abortion Ban: Honour, Shame, and the Possibility of a Moral Revolution." In The Abortion Papers Ireland: Volume 2, edited by Aideen Quilty, Sinead Kennedy, and Catherine Conlon, pp.167-78. Cork: Cork University Press.

. 2006. "The Cultural Politics of Sexuality and Reproduction in Northern Ireland.” Sociology 40(4), pp.663-80.

The Irish Times. 2017. "Bríd Smith Becomes First TD to Speak Publicly about Her Abortion." The Irish Times, June 29 [last accessed 22 December 2017]. - 2016. "Ms Y, Asylum Seeker Refused an Abortion, Sues State." The Irish Times, March 18. https://www.irishtimes.com/news/crime-and-law/courts/highcourt/ms-y-asylum-seeker-refused-an-abortion-sues-state-1.2578920 [last accessed 15 November 2017].

. " "Ms Y' Court Challenge to Stop HSE Inquiry into Her Care Is Struck out." The Irish Times, November 3, 2015. https://www.irishtimes.com/news/crimeand-law/courts/high-court/ms-y-court-challenge-to-stop-hse-inquiry-into-hercare-is-struck-out-1.2415545 [last accessed 15 November 2017]. 
. 2010. "Timeline: The Referendums, the X Case and European Court Challenges." The Irish Times, December 17.

Yuval-Davis, Nira. 1998. Gender and Nation. London: Sage. 